\title{
CASE STUDY OF COVID-19 IN PATIENTS ADMITTED TO A CAMPAIGN HOSPITAL IN THE CITY OF RECIFE: A RETROSPECTIVE STUDY
}

\author{
Simone Souza de Freitas, Mariana Galdino dos Santos Nunes², Maria Fernanda da Silveira \\ Scarcella $^{3}$, Raniele Oliveira Paulino ${ }^{4}$, Shelma Feitosa dos Santos ${ }^{5}$, Marília Rodrigues Feitoza 6 , \\ Larissa Regina Alves de Moraes Pinho7, Lígia Ferreira de Lima ${ }^{8}$, Thaizy de Moraes Ramos ${ }^{9}$, José \\ Jamildo de Arruda Filho ${ }^{10}$, Caline Sousa Braga Ferraz ${ }^{11}$, Cinthia Furtado Avelino ${ }^{12}$, Cinthia \\ Regina Albuquerque de Souza13, Diana Cristina Didier Souza' ${ }^{14}$, Luciana dos Santos Lopes ${ }^{15}$, \\ Nara Gabriel Nigro Rocha' ${ }^{16}$, Dirlene Ribeiro da Silva ${ }^{17}$, Robson Gomes dos Santos ${ }^{18}$, Ailma de \\ Alencar Silva ${ }^{19}$, Werlany Ingrid da Silva Barbosa ${ }^{20}$ and Sandra Sotero Freitas de Araújo ${ }^{21}$
}

${ }^{1}$ Specialist Nurse in Public Health (FUTURA), ${ }^{2}$ Graduated in Nursing (UNIVERSE), ${ }^{3}$ Master in Nursing from (UFMG) ${ }^{4}$ Graduated in Nursing (UFPE), ${ }^{5}$ Surveillance Specialist in Health - Syrian Hospital Lebanese, ${ }^{6}$ Graduated in nursing (FACHO), ${ }^{7}$ Graduated in Nursing (FUNESO), Graduated in Nursing (FACHO), ${ }^{8}$ Graduated in Nursing (UFPE), Graduated in Nursing (FACHO), ${ }^{9}$ Graduated in Nursing (UFPE), ${ }^{10}$ Graduated in Nursing (UFPE), ${ }^{11}$ Residency in Child Health Nursing at (IMIP), ${ }^{12}$ Specialist in Didactic-Pedagogical for Nursing Education (UFPE), ${ }^{13}$ Specialization in Family Health (IBPEX), 14 Specialist in Nephrology (IESC), ${ }^{15}$ Graduated in Nursing (FACHO), ${ }^{16}$ Graduated in nursing (UPE), ${ }^{17} \mathrm{Graduated}$ in nursing (FASI), 18 Specialist Nurse in Mental Health (UFPB), ${ }^{19}$ Graduated in nursing (UNIVERSE), ${ }^{20} \mathrm{Graduated}$ in nursing (UNIVERSE), ${ }^{21}$ Graduated in Nursing (FACHO)

\section{ARTICLE INFO}

Article History:

Received $06^{\text {th }}$ March, 2021

Received in revised form

$14^{\text {th }}$ April, 2021

Accepted $03^{\text {rd }}$ May, 2021

Published online $26^{\text {th }}$ June, 2021

Key Words:

COVID-19, Coronavirus disease,

Epidemiological Monitoring,

Public Health.

*Corresponding author:

Simone Souza de Freitas

\begin{abstract}
Since it was detected in November 2019, the new coronavirus (SARS-CoV-2), has been expanding across different continents, having been characterized as the cause of the COVID-19 pandemic by the World Health Organization (WHO) in 2020.This is a study descriptive and retrospective of patients diagnosed with COVID-19, hospitalized in a field hospital in the city of Recife in the period from April 2020 to September 2020. The Campaign Hospitals dedicated to the care of clinical patients, victims of infectious diseases, have the following basic characteristics: rapid construction, a large-scale temporary structure. From April 2020 to September 2020, 1,592 cases of Severe Acute Respiratory Syndrome were confirmed in the hospital evaluated. There were 1,502 notifications and among these 90 were not notified because they had already been notified in emergency services with positive results. Regarding the reported cases, $54 \%$ of the individuals were male and the most affected were the age group between sixty and sixty-nine years old $363(22.8 \%)$.SARS is a notifiable disease; therefore, all suspected cases must be reported and investigated by the health services using the standard Notifiable Diseases Information System (SINAN).This study may provide subsidies to understand the aspects involved in the occurrence of the disease, so that the prevention and coping with COVID-19 are consistent with the assistance provided by health surveillance.
\end{abstract}

Copyright (C) 2021, Simone Souza de Freitas1 et al. This is an open access article distributed under the Creative Commons Attribution License, which permits unrestricted use, distribution, and reproduction in any medium, provided the original work is properly cited.

Citation: Simone Souza de Freitas, Mariana Galdino dos Santos Nunes, Maria Fernanda da Silveira Scarcella et al. "Case study of covid-19 in patients admitted to a campaign hospital in the city of recife: A retrospective study”, International Journal of Development Research, 11, (06), 47958-47961.

\section{INTRODUCTION}

Since it was detected in November 2019, the new coronavirus (SARS-CoV-2), has been expanding across different continents, having been characterized as the cause of the COVID-19 pandemic by the World Health Organization (WHO) in 20201.
Currently, the world is facing the pandemic caused by the new coronavirus, which is highly transmissible, bringing several impacts of morbidity and mortality on the health of the entire population, influenced by different factors, such as age and associated preexisting conditions2. Thus, the health team's understanding of the most common clinical, laboratory and radiological characteristics in this 
public can guide the assistance provided, qualifying care and minimizing complications3. In February 2019, given the saturation of health systems in a relatively short space of time in the state of Pernambuco, there was a need to expand the supply of beds through the creation of campaign hospitals to meet the demand for hospitalizations among COVID patients -194. Considering the behavior of the disease and the search for intensive care beds, occupation in the public network with $94 \%$ and, in the private network, $90 \% 5$. As well as the infirmary beds, the occupation of $79 \%$ and $51 \%$ in public and private networks, respectively6. The new coronavirus has the potential to generate rapid and large demand for hospital beds to treat infected patients, mixing with the need for Campaign Hospitals, whose main characteristic is a hospital structure that can be put into operation quickly, on a temporary basis, and, in most cases, aimed at caring for patients with similar clinical conditions, as a consequence of pandemics or natural or humancaused catastrophes7. It is important to emphasize that this is a disease without a specific treatment, and that, in the first cases, it proved to be capable of generating high demand for the need for hospitalization in hospital beds8. Campaign Hospitals were used on a world scale, for the last time, for the treatment of the Spanish flu pandemic, also a viral respiratory disease, for over a century9. The emergency caused by the new coronavirus through the first cases described in Wuhan, capital of the Hubei province in China in November 2019, left the world on alert because it is a new disease, caused by a respiratory virus 10 . It is important to emphasize that Field Hospitals, regardless of the reasons and urgency of their construction, must be planned, built and operated always thinking about the quality of care provided to patients and the safety of the health professionals responsible for operating the unit 11.

\section{METHODS}

Study design and population: This is a study descriptive and retrospective of patients diagnosed with COVID-19, hospitalized in a field hospital in the city of Recife in the period from April 2020 to September 2020. As an inclusion criterion, it was considered COVID19 and exclusion cases were patients admitted to other services, coming to the studied hospital from the first or more recurrence.Data were obtained through a detailed analysis of medical records and were recorded in a standardized notification form by the Ministry of Health for Severe Acute Respiratory Syndrome (SRAG), containing patient identification, demographic data, clinical evolution and complementary tests. The information was registered through the elaboration of an Excel spreadsheet, containing the variables and the results obtained from the analysis performed using tabwin.

General methodology for completing the Severe Acute Respiratory Syndrome notification form: Information related to SRAG, reported by the attending physicians, was recorded in closed fields with three response alternatives:

1 - yes, if the symptom/sign in question was reported;

2- no, if the symptom/sign in question was denied;

9 - ignored, if there is no record of this symptom/sign.

Demographic and identification data: The patient's identification number and the date of admission were initially recorded, that is, when the diagnosis and/or treatment of the first episode of SARS occurred. Subsequently, through the electronic medical record (MVPEP) and the notification form, the patient's name, dates of birth and hospital discharge were obtained. Through the notification form, it was possible to obtain the age and months of the patients.

Clinical examination data: The interview data were registered during the anaminesis performed during the hospitalization period. Information from the physical examination was obtained at this time and in two other periods. The first period brings data from the natural history of theSRAG, allowing the identification of its presentation without the influence of specific therapeutic measures. The second period comprised the improvement that patients usually experience in the first week of treatment. The last period was related to the moment of hospital discharge or death, providing clinical data after the longest period of therapeutic intervention, in most cases not coinciding with the end of treatment.

Physical exam: The main signs found in the medical records were: fever, cough, dyspnea, respiratory distress, asthenia, O2 saturation $<95$ others;

\section{Laboratory Tests}

Specific to the Severe Acute Respiratory Syndrome Real-time RTPCR tests were performed.

Statistical analysis: Descriptive statistical methods were used for analysis, such as relative and absolute frequency, proportions, means and standard deviation of categorical and numerical variables. The results were presented in percentages and graphs and tables, using Microsoft Office Excel 2010 software (version 8.1) and EpilnfoTM version 7.2.

Ethical aspects: The project was approved by the Research Ethics Committee (CAAE: 31682720.9.000.5201).

\section{RESULTS}

The Campaign Hospitals dedicated to the care of clinical patients, victims of infectious diseases, have the following basic characteristics: rapid construction, a large-scale temporary structure. We will discuss these concepts using as a reference the Campaign Hospital of the city of Recife located in the neighborhood of rabbits to fight COVID-19. From April 2020 to September 2020, 1,592 cases of Severe Acute Respiratory Syndrome were confirmed in the hospital evaluated. There were 1,502 notifications and among these 90 were not notified because they had already been notified in emergency care services with positive results (Table 1). Regarding the reported cases, $54 \%$ of the individuals were male and the most affected were the age group between sixty and sixty-nine years old $363(22.8 \%)$, seen in (Graph 1). As for the origin of the cases in our study, the municipalities were observed according to Geres.The municipalities that are part of each Geres, respectively with the highest incidence of I Geres disease were Recife with 855(53.71\%), Jaboatão dos Guararapes with 137 (8.61\%) and Olinda with 85(5.34\%) cases; from II Geres Carpina with 16 (1.01\%) and Nazare da Mata with $9(0.57 \%)$ cases; in III Geres Escada with 7 (0.44\%) cases; in IV Geres Caruaru with $47(2.95 \%)$ and Gravata with $20(1.26 \%)$ cases; in V Geres Garanhuns with $3(0.19 \%)$ cases and in VI Geres Tacaratu with 2 $(0.13 \%)$ cases. In X Geres, the city of Tabira presented 3 cases $(0.19 \%)$ cases; in XI Geres they presented $1(0.6 \%)$ cases, in XII Geres Timbauba with $12(0.75 \%)$ and Goiana $6(0.38 \%)$ cases. In relation to VII, VIII and IX, all cities that are part of these geres presented a case $(0.6 \%)$ of COVID-19 in the study. Among the clinical manifestations presented by the patients in the study, respiratory distress was the main reason for alerting them to seek assistance.

In addition to respiratory distress, $\mathrm{O} 2$ saturation $<95 \%$ were also frequent symptoms, followed by dyspnea, cough, fever, anosmia and sore throat. When considering the occurrence of symptoms that are not characteristic of Severe Acute Respiratory Syndrome, gastrointestinal phenomena were also described. The main form of diagnosis was through RT PCRwhere it is based on real-time nucleic acid (RNA) detection of the COVID-19 virus. They represent the gold standard method for detecting infection in its acute phase, both in symptomatic and asymptomatic individuals.It should be noted that the collection of material is carried out in a hospital environment, in view of all biosafety instructions. They must be obtained from the upper airway, with nasopharyngeal or oropharyngeal swabs, preferably combined. There was a $75.53 \%$ positivity in this test in our study. The remaining cases were confirmed by epidemiological and clinical criteria. 
Center for endemics and medical analysis of paulista

Hospital medicine center

Hemope foundation

Fusam regional hospital of agreste dr waldemiro ferreira

Hgg dr paulo da veiga pessoa

Hla diagnosis

Agamenon magalhaes hospital

Belarmino correia hospital

Reef women's hospital

Hospital of restoration

Covid campaign hospital 19 de passira

Hospital de specialidades de camaragibe aristeu chaves

Hospital district escada dr benevolo wanderley do amaral

District hospital maria amalia b bezerra de melo

Dom helder camara hospital

Hospital general de paudalho

Getulio vargas hospital

Jaboatao pleasures hospital

Joao de vitoria santo antão hospital

Joao murilopoliclinica de vitoria hospital

Jaboatao memorial hospital

Master vitalino hospital

Miguel arraes hospital

Adolpho pereira carneiro municipal hospital

Our lady of graças hospital

Oswaldo cruz hospital

Otavio de freitas hospital

Hospital pelopidas silveira

Petronila campos hospital

Hospital prontolinda

Hospital regional de palmares dr silvio magalhaes

Dom moura regional hospital

Rui de barros correia regional hospital

Hospital santo amaro

Hospital sao sebastiao

Hpr i temporary hospital of recife santo amaro

Hpr ii provisional hospital of recife coelhos

Hpr iii provisional hospital of recife imbiribeira

Imip

Instituto aggeu magalhaes

Municipal laboratory of ipojuca

Dr zeferino veloso municipal laboratory

Policlinica dr manoel gomes de sa

Galvao polycline towers

Psf bar plant

Real portuguese hospital

Recife

Agrestin health secretary

Calf health secretary

Tamandare health secretary

Department of health of the state of pernambuco

Tabira municipal health secretary

Recife municipal health secretary

Elvira valenca borba mixed cutting unit

Joana amelia cavalcanti mixed unit

Mixed unit our lady of fatima

President castelo branco mixed unit

Mixed unit professor jorge oliveira lobo

Santa quiteria mixed unit

Upa

24-hour upa timbauba pe

Raft bar upa

Upa boa vista dr amorim

Upa cabo de santo agostinho

Upa caruaru

Upa caxanga

Upa cured

Upa old engineering

Upa ibura

Upa igarassu

Upa imbiribeira

Municipal upa of santa cruz do capibaribe

Upa new discovery

Upa olinda

Upa paulista

Upa sao lourenco da mata

Upa cutters

Broom upa

Upae goiana temporary hospital

Us 115 hospital general of sands

Us 143 recife municipal laboratory

Us 153 arnaldo marques polyclinic and maternity

Us 159 polyclinical agamenon magalhaes

Us 167 prof barros lima mixed unit

Us 169 amaury coutinho polycline

Grand total

For the treatment of SARS, the drug initially used in $84 \%$ of cases was azithromycin, followed by ceftriaxone $84 \%$. For the period from April 2020 to September 2020, there was a cure in 211 of the confirmed cases (13.25\%) followed by an improved discharge
(49.43\%) of the cases. Already (27.32) evolved to death due to the disease $(0.38 \%)$ discharged due to evasion, and $(8.17 \%)$ cases were transferred to other hospital units as seen (Graph 2).
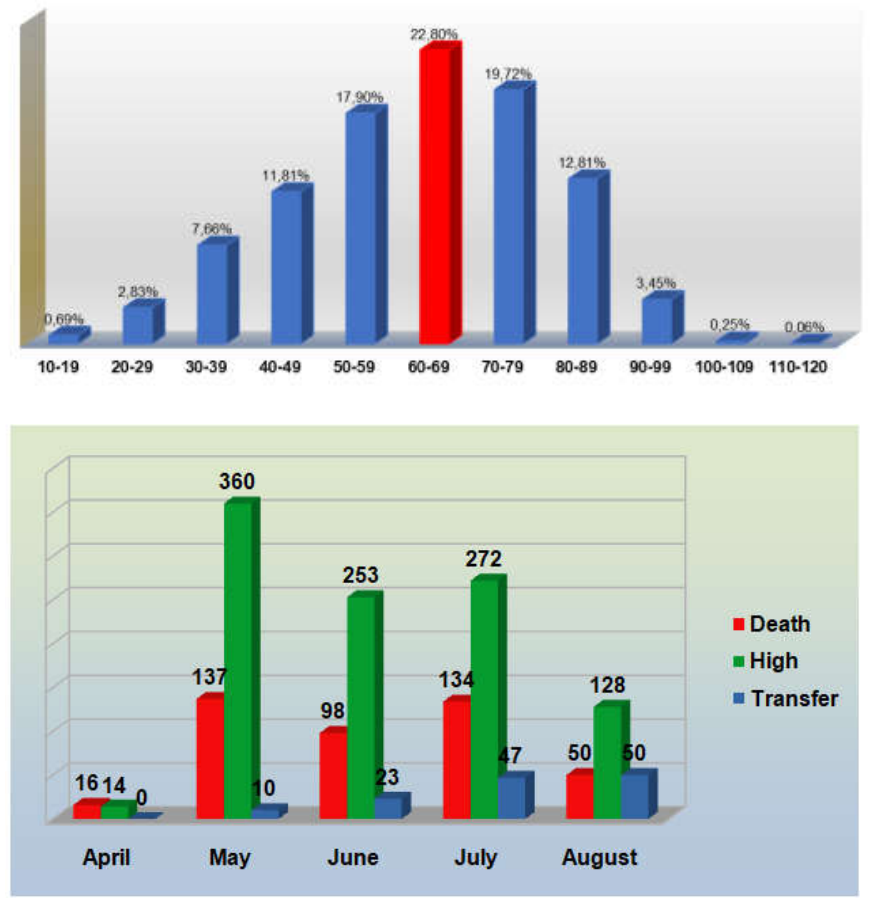

\section{DISCUSSION}

During the study period, according toEpidemiological Report No. $151 / 2020$ were registered almost 2,552,265 of cases of respiratory diseases in the SUS, in the Northeast region of the country, of which the state of Pernambuco was responsible for about 23,393 of confirmed SARS cases for Covid-19, by sex. SARS is a notifiable disease; therefore, all suspected cases must be reported and investigated by the health services using the standard Information System for Notifiable Diseases (SINAN) (Brazil1). This is a disease that has a high number of cases that evolve to death when associated with the new coranoavirus, even considering the methods used for diagnosis, and the fact that there is no effective and free treatment provided by the Unified Health System (SUS), in which the population can be treated in a timely manner. According to our study, of the 1,592 cases included, $46 \%$ of those affected by COVID-19 were female. This situation, according to the Information Department of the Brazilian Unified Health System (DATASUS), is related to the behavior of the disease and p.ostensibly, the greater involvement of the female gender reflects the greater care that women tend to have with their own health.Among the 1,592In cases studied at the hospital, it was observed that the most affected age group were people aged between sixty and seventy years old, which is in agreement with most studies that show greater involvement in years (45.7\%). This age group prevalence was also seen in the study in the same period by (FIOCRUZ, 2020). It is likely that the greater susceptibility to SARS infection in the elderly, especially in the group over 60 years of age, is due to the fact that these people live with young people at home, in addition, many have comorbidities associated with COVID-19 such as arterial hypertension systemic disease, diabetes mellitus and cardiovascular disease.The clinical manifestations presented by the study subjects did not differ from those classically found in the literature, both in terms of symptoms reported by patients and physical signs upon admission. In our sample, respiratory distress was the determining clinical sign for seeking medical care, data similar to those reported by (GHOSAL, 2020) and (Brazil,2021). With the present study, it was possible to observe that COVIS-19 associated with SRAG is present throughout the territory of Pernambuco, with cases registered in all Health Regions. COVID-19 is present in rural and urban areas, with the highest coefficients incidence in the Metropolitan Region of Recife, representing a public health problem. 
This study may provide subsidies to understand the aspects involved in the occurrence of the disease, so that the prevention and coping with COVID-19 are consistent with the assistance provided by health surveillance. Considering the results found, it is necessary to develop environmental interventions that reduce risk factors, being essential the constant updating of health professionals. Thus,

\section{REFERENCES}

Albuquerque, nlsd, \& pedrosa, nl (2020). Spatial analysis of COVID19 cases and intensive care beds in the state of Ceará, Brazil.Ciência \& Saúde Coletiva, 25, 2461-2468.

Brasil. Ministry of Health (MS). Integrated Health Surveillance Platform. Notification of cases by the new coronavirus (COVID-2019) [Internet]. [accessed 2020 Jun 20]. Available at: http://plataforma.saude.gov.br/novocoronavirus/dados-abertos/» http://plataforma.saude.gov.br/novocoronavirus/dados-abertos/

Ferreira, MRS 2013. The discursive construction of urban sustainability in the Microregion of Garanhuns-PE. Federal University of Sergipe (UFS). Available in: https://ri.ufs.br/handle/riufs/4274

Generation of models from existing models' composition: An application to agrarian sciences. PloS one, 14(12), and 0214778. doi: https://doi.org/10.1371/journal.pone. 0214778

Ghosal, S., Sengupta, S., Majumder, M., \& Sinha, B. (2020). Linear Regression Analysis to predict the number of deaths in India due to SARS-CoV2 at 6 weeks from day 0(100 cases -March 14th2020). Diabetes \& metabolic syndrome. Advance online publication,14(4), 311-315. doi: https://doi.org/10.1016/ j.dsx.2020.03.017

Laird, AK 1965. Dynamics of relative growth. Growth, Ministry of Health [MS] (2020). Coronavirus Panel, 29(9), 249-263. Available at: https://covid.saude.gov.br/

OSWALDO CRUZ FOUNDATION (FIOCRUZ) (2020). Study points out the internalization of Covid-19 in Pernambuco. Available at: https://portal.fiocruz.br/noticia/estudo-apontainteriorizacao da covid-19 in Pernambuco.

Research, Society and Development, 9(6), 117963561. doi: http://dx.doi.org/10.33448/rsd-v9i6.3561.

Rodriguez-Morales, AJ, Gallego, V., Escalera-Antezana, JP, Méndez, CA, Zambrano, LI, Franco Paredes, C., ... \& Risquez, A. (2020). COVID-19 in Latin America: The implications of the first confirmed case in Brazil. Travel medicine and infectious disease, 35, 1-4.doi: 10.1016/j.tmaid.2020.101613
Santiago, EJP, da Silva Freire, AK, Cunha Filho, M., Moreira, GR, de Almeida Ferreira, DS, \& Cunha, ALX (2020). Non-linear models applicable to mortality and cases of COVID-19 in Brazil, Italy and the world.

Santos, ALP, Figueiredo, M., Ferreira, T., Gomes-Silva, F., Moreira, G., Silva, J., \& Freitas, J. (2020). Analysis and forecasting of the evolution of COVID-19 death numbers in the state of Pernambuco and Ceará using regression models. Research, Society and Development, 9(7), e602974551. doi: http://dx.doi.org/10.33448/rsd-v9i7.4551.

Santos, ALP, Moreira, GR, Gomes-Silva, F., Brito, C., da Costa, M., Pereira, L., Maurício, RM, Azevêdo, J., Pereira, JM, Ferreira, AL, \&Filho, MC (2019).

Silver, DN, Rodrigues, W., \& Bermejo, PH (2020). Temperature significantly changes COVID-19 transmission in (sub)tropical cities of Brazil. Science of the Total Environment, 729.1-7. It hurts:https://doi.org/10.1016/j.scitotenv.2020.138862

State agency for planning and research of pernambuco condepe/fidem. 2010. Sectoral composition of gross value added (gva). Recife: condepe/fidem.

Von On Bertalanffy, L. 1957. Quantitative laws in metabolism and growth. The Quarterly Review of Biology, 32(3), 217-231. It hurts:https://doi.org/10.1086/401873

World Health Organization, Who Director General's Remarks at the Media Briefingon 2019-nCoV on 11 February2020, (2020a). Available https://www.who.int/dg/speeches/detail/whodirector-general-sremarks-at-the-media-briefing-on-2019-nv-on-11-february2020.

World Health Organization, Who Director General's Remarks at the Media Briefingon 2019-nCoV on 11 March 2020, 2020b. Available at: https://www.who.int/dg/ speeches/detail/whodirector-general-s-opening-remarks-at-the-media-briefing-oncovid-19---11-march -2020.

YANG, W., Zhang, D., Peng, L., Zhuge, C., \& Hong, L. (2020). Rational evaluation of various epidemic models based on the COVID-19 data of China. (1). arXiv preprint arXiv:2003.05666. 